\title{
Etnografi Konflik Masyarakat Batu Daya dengan Perusahaan PT. Swadaya Mukti Prakarsa di Simpang Dua, Ketapang, Kalimantan Barat
}

\author{
Arkanudin \\ Fakultas Ilmu Sosial dan Ilmu Politik, Universitas Tanjungpura \\ Email: arkandien@yahoo.co.id \\ Rupita \\ Fakultas Ilmu Sosial dan Ilmu Politik, Universitas Tanjungpura \\ Email:rupita_iin@yahoo.com
}

Naskah diterima: 10 Januari 2020 | Naskah disetujui: 10 Februari 2020

\begin{abstract}
The natural and social environmental impacts of the expansion of palm oil plantation companies have invited many protests from the local communities and local NGOS. The many consequences of this expansion have been documented to include increasingly the deforesation and conversion of forest areas. Then invites polemic and conflict between oil palm plantation companies and local communities. In this study took place in Batu Daya village of Ketapang Regency, where indigenous peoples and local communities who have settled hereditary and actively use the forest for daily needs and make a living, according to indigenous knowledge and traditions. They must participate in the games of palm oil companies in the management of their private land. This research uses qualitative methods with ethnographic approaches, where the analysis of conflicts as data analysis. The data used is primary data through interviews and observations in the field, then secondary data comes from village government documents, corporate documents, government regulations and scientific journals. The findings of this research is a communal conflict that occurred between the Palm Plantation company PT. Nongovernmental Mukti initiative with the community in Batu Daya Village, due to changes in the socio-economic structure of the community traditional landscape on the potential of natural wealth to the capitalist system through the core and plasma patterns. Then, the process of communal conflict between palm plantation company PT. Swadaya Mukti Perkasa with the people of Batu Daya village as a result of the society felt not to get enlightened life as hope. The communal conflict between the palm Plantation company PT. Non-governmental Mukti initiative with the people of Batu Daya village has actually been mediated by local NGO's in West Kalimantan.
\end{abstract}

Keywords: Conflict, Palm Oil, Company, Customary Community

\begin{abstract}
Abstrak
Terjadinya dampak lingkungan alam dan sosial dari ekspansi perusahaan perkebunan kelapa sawit banyak mengundang protes dari masyarakat, komunitas lokal dan LSM lokal. Banyaknya akibat dari ekspansi ini berhasil didokumentasikan meliputi deforesasi yang semakin merajalela dan konversi wilayah hutan yang luas. Hal ini kemudian mengundang polemik dan konflik antara perusahaan perkebunan sawit dengan masyarakat lokal. Pada penelitian ini mengambil lokasi di Desa Batu Daya Kabupaten Ketapang, dimana masyarakat adat dan komunitas lokal yang telah menetap secara turun-temurun dan secara aktif menggunakan hutan untuk kebutuhan sehari-hari dan mencari nafkah, sesuai dengan pengetahuan dan tradisi adat. Mereka harus ikut ke dalam permainan perusahaan kelapa sawit dalam pengelolaan lahan
\end{abstract}


milik pribadi. Penelitian ini menggunakan metode kualitatif dengan pendekatan etnografi, dimana analisis konflik sebagai pisau analisa data. Data yang digunakan adalah data primer melalui wawancara dan observasi di lapangan, kemudian data sekunder berasal dari dokumen pemerintahan desa, dokumen perusahaan, peraturan pemerintah dan jurnal ilmiah. Temuan penelitian ini yaitu konflik komunal yang terjadi antara Perusahaan Perkebunan Sawit PT. Swadaya Mukti Prakarsa dengan masyarakat di Desa Batu Daya, disebabkan perubahan struktur sosial-ekonomi masyarakat dari sistem peladangan tradisional atas potensi kekayaan alam ke sistem kapitalis melalui pola inti dan plasma. Kemudian, proses konflik komunal antara Perusahaan Perkebunan Sawit PT. Swadaya Mukti Prakarsa dengan masyarakat Desa Batu Daya sebagai akibat dari masyarakat merasa tidak mendapatkan pencerahan hidup sebagaimana harapan (untung-rugi yang tidak jelas). Konflik komunal antara Perusahaan Perkebunan Sawit PT. Swadaya Mukti Prakarsa dengan masyarakat Desa Batu Daya sebenarnya telah ditengahi oleh berbagai LSM lokal di Kalbar.

Kata Kunci: Konflik, Kelapa Sawit, Perusahaan, Masyarakat Adat

\section{Pendahuluan}

Perkembangan pesat lahan kelapa sawit juga terjadi di Kalimantan Barat. Peningkatan luas areal lahan kelapa sawit tersebut, juga menjadi indikasi dari peningkatan jumlah perusahaan industri pengolahan kelapa sawit di Kalimantan Barat. Data GAPKI Kalbar (2016) menyebutkan sebanyak 64 perusahaan pengolahan kelapa sawit yang beroperasi di Kalbar, yang terdiri atas 5 perusahaan milik negara dan 59 perusahaan milik swasta.

Sudah bukan merupakan sesuatu yang mengejutkan lagi bahwa ekspansi perkebunan kelapa sawit dalam banyak kasus telah memiskinkan petani setempat dan menyebabkan konflik lahan. Perkebunan kelapa sawit sudah seharusnya menjadi proses pembangunan yang adil melalui reformasi tata kelola, kebijakan dan hukum untuk melindungi hak-hak masyarakat adat dan petani hak atas tanah, mencegah 'perampasan tanah', memastikan proses negosiasi atas tanah yang adil, membangun kapasitas masyarakat dan menjamin adanya mekanisme untuk penyelesaian konflik lahan.

Akibat kurangnya penghormatan terhadap hak-hak masyarakat setempat atas tanah adat masyarakat lokal, konflik tanah dengan beragam tingkat keseriusan marak terjadi di sebagian besar perkebunan, mulai dari perselisihan sepele atas tanah, sampai protes seluruh desa, demonstrasi, blokade dan kasus-kasus pengadilan yang berkepanjangan. Sementara perusahaan-perusahaan tertentu telah mengembangkan mekanisme untuk menyelesaikan konflik ini, fokus mereka adalah pada pembentukan proses penyelesaian konflik itu sendiri, bukan pada efisiensi proses ini untuk benarbenar menyelesaikan konflik. Pengembangan SOP penyelesaian konflik di atas kertas 
oleh perusahaan dipandang oleh sebagian masyarakat sebagai strategi untuk sungguhsungguh menghindari berurusan dengan masalah di lapangan.

Sutaryono, dkk., (2012) menyebutkan bahwa tidak seperti di daerah lain yang menunjukkan bahwa konflik agraria merupakan resistensi dan perlawanan atas ekspansi brutal perusahaan pertambangan-perkebunan karena dinilai mengancam tanah-tanah rakyat seperti terjadi di Bima provinsi Nusa Tenggara Barat, Pesisir Kulonprogo provinsi D.I. Yogyakarta, dan Mesuji provinsi Lampung dan Sumatera Selatan; namun apa yang terjadi di Kab. Sarolangun dalam argumen ini adalah suatu gambaran konflik yang dimotivasi oleh terbendungnya akses rakyat untuk bisa terlibat dalam aktifitas perkebunan kelapa sawit.

Sejak tahun 2004/2005 sampai 2007/2008 minyak sawit mendominasi keseluruhan produksi minyak nabati dunia, melampaui minyak kedelai yang sampai tahun 2003 masih menjadi primadona minyak nabati dunia, kemudian minyak sawit Indonesia dan Malaysia pada tahun 2008 menguasai 85,8\% produksi minyak sawit dunia (Badrun, 2010).

Nasution (2008) menjelaskan bahwa industri kelapa sawit dalam perekonomian Indonesia mempunyai peran yang cukup strategis karena minyak sawit merupakan bahan utama minyak goreng, sehingga pasokan yang berkelanjutan akan menjaga kestabilan harga minyak goreng, menjadi salah satu komoditas pertanian andalan ekspor nonmigas, minyak sawit memiliki prospek yang baik sebagai sumber perolehan devisa maupun pajak, dan proses produksi maupun pengolahannya, kelapa sawit mampu menciptakan kesempatan kerja, sekaligus meningkatkan kesejahteraan bagi masyarakat.

Areal yang akan dibangun untuk perkebunan kelapa sawit di wilayah penelitian sebagian besar merupakan tanah ulayat masyarakat adat dan komunitas lokal lainnya. Dalam Undang-Undang Pokok Agraria No. 5 tahun 1960 hak atas tanah dapat dibedakan menjadi Hak Milik, Hak Guna Usaha, Hak Guna Bangunan, Hak Pakai, Hak Sewa, Hak Membuka Tanah, Hak Memungut Hasil Hutan, serta hakhak lain di luar hakhak tersebut. Berikut ini tata cara yang telah ditentukan dalam mengurus perizinan HGU perkebunan sawit.

Kemudian, terdapat hak adat atau hak ulayat atas tanah adat yang diakui dalam perundang-undangan negara (Sumardjono, 2010). Konversi tanah yang termasuk dalam komunitas adat menjadi tanah untuk pembangunan bisa saja dilakukan berdasarkan 
Peraturan Menteri Agraria/BPN No 5 Tahun 1999, Pasal 4b peraturan ini menyatakan bahwa konversi tanah milik masyarakat adat kepada departemen pemerintah, individu di luar anggota masyarakat adat, serta badan usaha dapat dilakukan sesudah tanah tersebut dibebaskan oleh komunitas adat sesuai dengan hukum adat masyarakat tersebut.

Masyarakat adat (indigenous peoples) merupakan kelompok yang memilki sejarah perkembangan masyarakat dengan wilayah, kehidupan ekonomi, termasuk budaya dan bahasa bersama. Menurut Sirait (2009), masyarakat adat terbiasa menguasai dan mengelola tanah adatnya secara bersama-sama atau sendiri-sendiri dengan menggunakan sistem penguasaan tanah yang diatur sesuai aturan adat dan kelembagaan adat mereka.

Kemudian, dapat dijelaskan bahwa masyarakat lokal memiliki hak legal serta hak tradisional dalam perihal pengelolaan sumber daya alam lokal. Hal legal ini berdasarkan hukum negara yang khusus mengatur hak ulayat adat. Kemudian, hak-hak tradisional terkandung pada nilai serta sistem adat yang berlaku pada masyarakat lokal tersebut.

Pada umumnya komunitas adat menganggap bahwa semua tanah yang pernah mereka garap untuk berbagai keperluan adalah tanah milik mereka baik secara individu maupun secara bersama-sama, meskipun tanah-tanah tersebut tidak didukung oleh dokumen kepemilikan seperti yang digariskan oleh peraturan perundang-undangan. Artinya dapat diketahui bahwa masyarakat adat merupakan komunitas lokal yang dilingungi hak-hak konstitusionalnya dalam rangka pengelolaan sumber daya alam dengan sistem dan pengetahuan lokal yang dimiliki. Artinya bahwa masyarakat adat memiliki kedaulatan khusus dalam pengelolaan sumber daya alam, termasuk didalamnya tanah adat.

Berdasarkan uraian diatas, dapat dijelaskan bahwa perkebunan kelapa sawit merupakan perusahaan perkebunan yang dilindungi oleh undang-undang agraria, yang mana terdapat aturan, persyaratan serta hak-hak yang perlu diperhatikan oleh perusahaan. Oleh karena itu, dengan dasar hukum yang jelas, perusahaan dapat berdiri pada level nasional, lokal hingga internasional.

Kemudian, keberadaan perusahaan kelapa sawit di Kabupaten Ketapang disinyalir terdapat kecurigaan dari kelompok masyarakat lokal. Hal ini karena pihak perusahaan kelapa sawit kemudian diduga mencaplok tanah-tanah masyarakat lokal. 
Menurut Teori Konflik Dahrendorf (1990) dinyatakan bahwa salah satu faktor yang sangat penting yang dapat mempengaruhi tingkat kekerasan dalam konflik kelas, yaitu tingkat yang menyatakan bahwa konflik itu secara tegas diterima dan diatur.

Pada hakikatnya konflik tidak dapat dilenyapkan karena perbedaan di antara mereka merupakan sesuatu yang harus ada dalam struktur hubungan otoritas. Konflik yang ditutup-tutupi, cepat atau lambat pasti akan muncul, dan apabila upaya penutupan itu secara terus-menerus maka dapat menyebabkan ledakan konflik yang hebat. Berdasarkan hal tersebut di atas maka perlu dibentuk saluran-saluran yang berfungsi membicarakan resolusi konflik.

Kemudian, Galtung (1990, dalam Susan, 2010) memberi definisi pada kekerasan budaya yaitu kekerasan budaya adalah aspek-aspek dari kebudayaan, ruang simbolis dari keberadaan masyarakat manusia-dicontohkan oleh agama dan ideologi, bahasa dan seni, ilmu pengetahuan empiris dan formal (logis, matematis)-yang bisa digunakan untuk menjustifikasi atau melegitimasi kekerasan struktural dan langsung. Pada kasus konflik antara masyarakat dengan perusahaan sawit di Kabupaten Ketapang, Kalimantan Barat kecurigaan yang kemudian mengarah kepada kecurigaan perampasan hak-hak warga lokal. Dari sinilah muncul ketakutan masyarakat kalau perusahaan kelapa sawit akan merampas hak-hak masyarakat lokal, kemudian terjadi lah kekerasan kultural yang muncul sebagai hasil konstruksi masyarakat.

Menurut Dahrendorf (1959) usaha yang mencoba untuk menekan atau menghapuskan pertentangan tersebut adalah sia-sia. Dalam masyarakat modern pertentangan itu harus diatur melalui institusionalisasi sehingga dengan demikian kepentingan yang bertentangan itu disadari. Pengaturan konflik yang terjadi didasarkan pada pengakuan yang eksplisit akan kenyataan dan kebenaran adanya konflik; artinya kedua belah pihak dilihat sebagai memiliki kepentingan yang saling bertentangan secara sah.

Kemudian, juga pengaturan konflik menuntut pembentukan kelompok kepentingan yang terorganisasi dan ditegakkannya suatu kerangka bersama untuk merembuk perbedaan-perbedaan itu. Konflik agraria di perkebunan tidak saja menghadapkan pihak perkebunan dengan petani penggarap, tapi juga berhadapan dengan masyarakat adat (Bahari, 2004). 
Pada beberapa kajian disebutkan beberapa dampak negatif dari adanya kelapa sawit menurut Marti (2008, dalam Surambo, dkk., 2010) yakni: a) banyak masyarakat adat kehilangan tanah dan akses ke air serta tidak mendapat penghidupan yang layak; b) Komunitas-komunitas yang dulunya mandiri dalam memenuhi kebutuhan sehari-hari, sekarang terjerat hutang dan harus berjuang keras untuk memperoleh akses ke pendidikan dan memenuhi kebutuhan pangan mereka; c) Tradisi dan budaya juga turut hancur oleh proses ekspansi perkebunan kelapa sawit, sejalan dengan rusaknya hutan dan satwa serta tumbuhan liar di Indonesia; d) Beberapa komunitas mengalami pelanggaran hak asasi manusia dan hak-hak perempuan-termasuk hak atas air, kesehatan, pekerjaan, budaya, dan hak untuk dilindungi dari perlakuan buruk dan kesewenang-wenangan. Wibowo (2016) menyebutkan bahwa tanaman sawit memiliki pengaruh dalam perubahan iklim yang ada di Indonesia.

Kajian ini lebih ke penelusuran konflik yang terjadi antara masyarakat di Desa Batu Daya dengan perusahaan sawit PT. Swadaya Mukti Prakarsa, yang mana masyarakat yang menjadi korban atas perampasan tanah dan lahan oleh perusahaan. Kemudian, mengungkapkan faktor-faktor yang menjadi penyebab konflik antara masyarakat di Desa Batu Daya dengan perusahaan kelapa sawit PT. Swadaya Multi Prakarsa.

\section{Metode}

Jenis penelitian ini adalah penelitian kualitatif deskriptif, dengan pendekatan etnografi. Etnografi dipilih menjadi metode penelitian karena tujuan utama etnografi adalah untuk memahami cara hidup masyarakat lain dari sudut pandang pelaku atau pemangku (aktor) kebudayaan tersebut. Metode ini melibatkan peneliti untuk terlibat secara langsung di lapangan penelitian dengan masyarakat yang diteliti. Dengan begitu peneliti juga dituntut untuk mengamati dan belajar dengan objeknya secara langsung, mendengarkan perbincangan, mengikuti aktivitas, memahami cara berfikir, dan lain sebagainya.

Kemudian, data yang digunakan dalam penulisan artikel ini yaitu eksplorasi data sekunder dan primer. Data sekunder dalam penelitian ini dengan penelusuran tulisan-tulisan ilmiah seperti jurnal dan buku yang terkait dengan tema tulisan. Selain itu, data sekunder juga menggunakan dokumen perusahaan dan dokumen 
desa. Kemudian, eksplorasi data primer yaitu dengan bercakap (berinteraksi), beraktivitas dan wawancara mendalam. Penulisan laporan penelitian berbarengan saat peneliti di lapangan, sehingga verifikasi data lapangan dilakukan setelah data sudah lengkap.

\section{Konflik Masyarakat Desa Batu Daya dengan Perusahaan Perkebunan Sawit}

Konflik agraria khususnya di Desa Batu Daya, mulai menjadi sangat massif bermunculan terutama sejak daerah ini membuka ratusan ribu hektar tanahnya untuk penanaman komoditas sawit. Daerah ini telah mengalami beberapa fase perubahan tata guna lahan. Jauh sebelum sawit masuk, masyarakat Batu Daya melakukan budi daya padi ladang, karet rakyat yang dikombinasikan dengan tanaman buah-buah atau tanaman untuk kerajinan seperti rotan dan bambu. Menurut informan masyarakat Batu Daya yang diwawancarai menyebutkan bahwa:

"Pada masa dahulu, daerah Batu Daya ini bukan areal perusahaan sawit. Walaupun sawit sudah lama ada di desa ini, tapi perusahaan belum merambah sampai ke kebun-kebun masyarakat. Sekarang ini kan desa ini sudah areal perusahaan"

Masyarakat di Desa Batu Daya yang resisten terhadap ekspansi perkebunan kelapa sawit, telah mengarah pada sejumlah konflik. Perusahaan yang masuk di desa tersebut menuai konflik dengan alasa berikut, yaitu: (1) ekspansi perkebunan kelapa sawit telah merambah hingga areal hutan dan tanah adat masyarakat lokal; dan (2) desakan kebutuhan sosial ekonomi masyarakat, ditambah industri perkebunan kelapa sawit kurang dapat meningkatkan taraf kehidupan masyarakat (untung-rugi dan harga yang tidak stabil).

Akar konflik antara masyarakat dengan pihak perusahaan sawit di Desa Batu Daya dikarenakan adanya ketidaksepahaman antar kedua belah pihak. Konflik akan penggunaan dan kepemilikan lahan menjadi titik penting dalam menyoroti konflik komunal antara masyarakat dengan perusahaan sawit. Kebijakan pertanahan Indonesia di beberapa dekade terakhir, utamanya pada abad ke-21 dicirikan dengan besarnya pengalokasian dan peruntukan tanah untuk kepentingan non-pertanian dalam skala besar. Hal ini berakibat pada pembabatan dan pembukaan lahan non-pertanian. Jika kita melihat perubahan penguasaan, pemilikan, penggunaan dan pemanfaatan tanah dari tahun ke tahun, terdapat ketimpangan yang luar biasa bagi lahan pertanian. 
Berdasarkan hasil kajian tim peneliti dari Universitas Tanjungpura dan Universitas Palangkaraya pada tahun 2013 tentang dampak sosial pembangunan perkebunan kelapa sawit di tahun 2012, mengemukakan bahwa penggunaan lahan untuk kelapa sawit tidak mengurangi hak berdasarkan hukum dan hak tradisional pengguna lain tanpa persetujuan terlebih dahulu dari para pemilik lahan tradisional. Proses negosiasi antara pemilik hak tradisional dan perusahaan telah dilaksanakan, namun rekaman proses negosiasi tidak tersedia.

Kemudian, tidak tersedia peta dalam skala yang memadai yang menggambarkan wilayah-wilayah di bawah hak-hak tradisional yang diakui. Hal ini menunjukkan bahwa masyarakat lokal tidak memiliki dokumen kepemilikan lahan, yang dapat memperkuat bahwa adanya hak ulayat adat pada wilayah tersebut. Pada dasarnya pihak perusahaan sudah kelakukan kegiatan sosialisasi sebelum pengembangan areal perkebunan kelapa sawit, yang kemudian disebutkan dalam SOP Proses perolehan HGU dan SOP Ganti Rugi Tanah/Lahan. Namun demikian, terdapat pihak-pihak masyarakat yang tidak puas dengan hasil sosialisasi yang dilakukan pihak perusahaan. Masyarakat mengaku bahwa proses untuk memperoleh HGU dan ganti rugi dinilai tidak jelas dan merugikan pemilik lahan.

Selain itu, memang kegiatan sosialisasi rencana pembangunan perkebunan kelapa sawit telah dilakukan sebelum kegiatan penanaman baru dilaksanakan, tetapi rekaman proses sosialisasi belum didokumentasikan dengan baik. Selain itu, materi sosialisasi belum mencakup analisis untung-rugi yang dapat membandingkan antara melepaskan lahan menjadi perkebunan kelapa sawit atau tetap mempertahankan lahan untuk penggunaan lain oleh pemilik lahan. Hal ini juga diakui oleh masyarakat setempat:

"Memang sosialisasi itu selalu ada. Selalu sosialisasi, namun ada kesepakatankesepakatan yang tidak disetujui masyarakat, ada yang tidak dibahas lagi. Jadi, hal-hal yang masyarakat inginkan, tidak diindahkan oleh perusahaan"

Hal ini untuk kepentingan dalam negosiasi, pihak perusahaan bersama-sama dengan pemilik hak dan pemerintah desa setempat membuat peta rinci yang disepakati dan disetujui bersama. Artinya bahwa dalam rangka pengurangan konflik, pihak perusahaan menghadirkan masyarakat adat setempat dalam memetakan wilayah yang akan menjadi lokasi pengembangan perkebunan kelapa sawit. 
Disamping itu, juga tersedia dokumen hasil kesepakatan antara pemilik lahan dan perusahaan yang tercantum dalam berita acara kesepakatan akhir yang ditandatangani oleh pemilik lahan, perusahaan, saksi-saksi, dan diketahui oleh Kepala Desa dan Camat setempat. Dokumentasi ini disimpan di perusahaan dan tidak diberikan kepada pemilik lahan dan pihak-pihak lainnya. Artinya, konflik dapat saja terjadi karena masyarakat lokal tidak diberikan hasil salinan dokumentasi (surat-menyurat/MoU) antara pihak perusahaan dan pihak masyarakat setempat. Pemicu konflik terjadi dikarenakan adanya ketidakpuasan sebelah pihak, yang kemudian menimbulkan percikan konflik. Masyarakat yang diwawancarai menyebutkan bahwa:

"Masyarakat itu punya dokumen, dibikin di kantor desa. Ada dokumennya. Surat-surat tanah kita bikinnya di kantor desa. Harusnya hak kita ada saat tanah kita mau di ambil perusahaan. Karena kan ada kita punya dokumen sah”

Berdasarkan pengakuan pihak perusahaan bahwa pembukaan lahan untuk pengembangan perkebunan pada perusahaan PT. Swadaya Mukti Prakarsa tidak dilakukan di hutan primer melainkan pada hutan sekunder, lahan terdegradasi, semak, bekas penebangan (Perusahaan Kayu), lahan bekas kebakaran hutan, dan lahan yang sudah ditinggalkan oleh peladang berpindah. Lokasi perkebunan kelapa sawit di Kalimantan Barat telah sesuai dengan tata ruang yaitu berada di lokasi Areal Penggunaan Lain (APL) sesuai dengan Kepmenhutbun No. 259/Kpts-11/2000 tentang Penunjukan Kawasan Hutan dan Perairan.

Pada dasarnya perusahaan PT. Swadaya Mukti Prakarsa telah memiliki dokumen Analisis Mengenai Dampak Lingkungan Hidup (AMDAL), Rencana Pemantauan Lingkungan (RPL), dan Rencana Pengelolaan Lingkungan (RKL) yang disusun oleh konsultan dan disahkan oleh aparat pemerintah yang berwenang serta melibatkan masyarakat dalam proses penyusunan dan pembahasannya. Tetapi, berdasarkan temuan peneliti di lapangan, laporan tersebut belum lengkap dan tidak mencakup dampak sosial ekonomi, dan program CSR (Corporate Social Responsibility) yang belum begitu jelas. Menurut pengakuan masyarakat yang diwawancarai menyebutkan:

"Memang ada beberapa kali ada acara dari perusahaan. Ada lah acara-acara gitu. Periksa kesehatan apa gitu. Tapi kan kompensasi untuk tanah masyarakat itu tidak sesuai, itu yang dituntut", 
Berdasarkan temuan lapangan, dapat diketahui bahwa identifikasi dan penilaian hak atas tanah berdasarkan hukum dan hak tradisional telah dilakukan oleh pihak PT. Swadaya Mukti Prakarsa. Ganti rugi telah dilakukan melalui negosiasi antara perusahaan perkebunan dengan pemilik lahan tradisional serta disaksikan oleh pejabat pemerintah setempat. Kemudian, terdapat indikasi bahwa pihak perusahaan mengambil lahan adat dijadikan lokasi penanaman pohon baru. Hal ini yang memicu perselisihan dan konflik, karena masyarakat tidak terima lahan adat yang diakui oleh desa kemudian diambil alih oleh pihak perusahaan.

Adapun proses yang dilakukan dalam menentukan kompensasi lahan yaitu mengikuti langkah-langkah berikut ini: (1) Mendapatkan pernyataan persetujuan oleh masyarakat secara umum untuk menyerahkan lahan; (2) Mengidentifikasi letak dan luasan lahan serta tanam tumbuh; (3) Menelusuri hak penguasaan lahan kepada pemilik lahan yang berbatasan langsung, tokoh masyarakat yang mengetahui sejarah lahan, dan Kepala Desa terkait; (4) Menuangkan hasil identifikasi ke dalam peta rincik; dan (5) Melakukan perundingan penentuan kompensasi dengan pemilik lahan atau kerabat yang mewakilinya.

Masyarakat yang kehilangan akses dan hak tanahnya diberi kesempatan untuk bekerja di perkebunan, menjadi kontraktor lokal, dan menjadi peserta program kemitraan perkebunan. Hal ini yang terjadi pada masyarakat di Desa Batu Daya, dimana masyarakatnya sebagian besar merupakan karyawan di PT. Swadaya Mukti Prakarsa. Keterlibatan masyarakat lokal di dalam perusahaan ini yang kemudian menjadi jalan tengah pereda konflik untuk sementara, dimana tuntutan masyarakat akan ganti rugi bisa di akali dengan memperkerjakan orang lokal.

Temuan lapangan menemukan bahwa perusahaan perkebunan menerapkan 2 status pekerja, yaitu Buruh Harian Lepas (BHL) dan Syarat Kerja Umum (SKU) H (harian) atau SKU B (bulanan). BHL dibayar berdasarkan Upah Minimum Regional (UMR) Provinsi atau UMR Kabupaten, dipilih yang lebih tinggi. BHL menerima upah tetap tanpa memperhitungkan masa kerja mereka dengan perusahaan. SKU dibayar dengan upah harian/bulanan ditambah dengan fasilitas dalam bentuk perumahan, listrik, air bersih, pelayanan kesehatan, asuransi tenaga kerja, dan tunjangan beras bulanan. Penelusuran lapangan menemukan bahwa warga lokal lebih banyak yang berstatus sebagai pekerja SKU dibandingkan BHL. 
Berdasarkan hasil wawancara dengan warga lokal yang memiliki status pekerjaan sebagai BHL, beberapa diantaranya mengharapkan perusahaan mempertimbangkan untuk menaikkan upah mereka di atas UMR, karena harga barangbarang kebutuhan hidup di sekitar perusahaan lebih tinggi dari harga di perkotaan. Selain itu, penghasilan di pedesaan dari pekerjaan lain misalnya menyadap karet sudah melebihi tingkat UMR, padahal jam kerjanya jauh lebih singkat dari jam kerja di perusahaan.

\section{Faktor Penyebab Konflik Masyarakat Batu Daya versus PT. Swadaya Mukti Prakarsa}

Keberadaan perusahaan perkebunan kelapa sawit di kawasan Desa Batu Daya bagai pisau bermata dua, di satu sisi telah menciptakan dampak sosial yang positif terhadap wilayah sekitar, misalnya menciptakan lapangan pekerjaan baru bagi masyarakat, meningkatkan pendapatan masyarakat sekitar, meningkatkan jumlah uang yang beredar di pasar desa, dan mendorong perkembangan peluang usaha. Namun, pada sisi lain keberadaan perusahaan sawit membawa dampak lain seperti konflik masyarakat dengan masyarakat dan masyarakat dengan perusahaan.

Pembangunan dan pemeliharaan jalan di perkebunan telah membuka akses wilayah pedesaan dan meningkatkan mobilitas orang dan barang serta menciptakan konektivitas yang mudah antara wilayah kota dan desa, antara kota dan kota, serta antara desa dan desa.

Hadirnya perusahaan perkebunan sawit di Desa Batu Daya telah membawa banyak perubahan, utamanya dalam pembangunan sosial ekonomi. interaksi sosial yang sebelumnya secara cuma-cuma di antara anggota lingkungan sosial, misalnya lahan, tenaga kerja, dan pelayanan, kini berubah statusnya menjadi benda-benda ekonomi yang hanya bisa diperoleh melaluimetode formal, prosedural dan nilai ekonomi.

Transformasi ini tidak serta merta dapat diinternalisasikan dengan kecepatan yang sama oleh masyarakat pedesaan, sehingga sering kali menimbulkan berbagai masalah. Perubahan tersebut, jika tidak dikelola dengan baik, maka dapat menimbulkan terjadinya konflik, menurunnya penghargaan terhadap institusi sosio kultural dan pemimpin informal, serta melemahkan solidaritas sosial sebagai akibat dari perubahan yang cepat. Oleh sebab itu, perusahaan perkebunan semestinya mengambil peran aktif 
dalam mengelola perubahan dan kemajuan sosial, seperti mendorong terbentuknya institusi perwakilan masyarakat yang bisa menjembatani hubungan antara perusahaan dan masyarakat, agar terjadi hubungan timbal balik antara pihak perusahaan dan pihak masyarakat.

Dampak negatifnya, menjadi pemicu konflik sosial antara masyarakat desa setempat dan pekerja perkebunan maupun pihak perusahaan sawit, serta mengarah pada pelanggaran hak asasi manusia, misalnya terjadi penangkapan paksa warga desa oleh aparat karena dituduh menjadi provokator dalam penolakan konsesi lahan oleh perusahaan. Kondisi faktual yang terjadi bahwa masuknya perkebunan sawit justru mengancam budaya tradisional dan ketahanan pangan masyarakat.

Secara khusus, keberadaan perusahaan perkebunan tanaman komersial sangat mempengaruhi pola produksi masyarakat dari usaha tani dengan produksi tanaman untuk pasar lokal dan berkembang dengan tanaman komersial yang berorientasi pada pasar yang luas. Relasi produksi dalam masyarakat untuk mengusahakan lahan pertanian sudah mengalami perubahan dari sistem gotong royong, menggunakan tenaga kerja bersama dan peralatan tradisional, digantikan tenaga upahan dan tenaga sendiri, bekerja berdasarkan kesepakatan, menggunakan modal, teknologi dan pengetahuan baru yang diperkenalkan oleh petugas pertanian dan perusahaan untuk budi daya pertanian, pengelolaan kebun sawit dan karet.

Pada era otonomi daerah, provinsi berwenang pada kawasan yang bersifat lintas Kabupaten/Kota. Karena tanah mempunyai nilai strategis dalam NKRI. Pada Keputusan Presiden No. 34/2003 tentang Kebijakan Nasional di Bidang Pertanahan, terdapat sembilan kewenangan Pemerintah di bidang pertanahan yang diserahkan kepada pemerintah Kabupaten dan Kota,yaitu sebagai berikut:

(1) Pemberian izin lokasi.

(2) Penyelenggaraan pengadaan tanah untuk kepentingan pembangunan.

(3) Penyelesaian sengketa tanah garapan.

(4) Penyelesaian ganti kerugian dan santunan tanah untuk pembangunan.

(5) Penetapan subjek dan objek redistribusi tanah serta ganti kerugian tanah kelebihan maksimal dan tanah absentee.

(6) Penetapan dan penyelesaian masalah tanah ulayat (tanah adat).

(7) Pemanfaatan dan penyelesaian masalah tanah kosong. 
(8) Pemberian izin membuka tanah.

(9) Perencanaan penggunaan tanah wilayah kabupaten/kota.

Kemudian, pada praktiknya, pada awal proyek, masyarakat tidak pernah diinformasikan dan diberikan informasi yang memadai oleh perusahaan tentang rencana proyek, maksud dan tujuan, rencana perolehan dan pemanfaatan lahan yang dimiliki warga dan lahan-lahan milik bersama warga desa untuk kepentingan perkebunan sawit. Perusahaan melakukan survei pengukuran, pematokan dan pemetaan lahan warga, serta penggusuran tanpa ada pemberitahuan dan persetujuan dari warga setempat. Perusahaan menggunakan tenaga lapangan, yakni: orang-orang tertentu yang dikenal "preman" yang bertugas melindungi aktifitas perusahaan dan dapat betindak melakukan intimidasi dan kekerasan terhadap warga.

Perusahaan melakukan sosialisasi rencana proyek setelah kegiatan pematokan dan penggusuran lahan sudah berlangsung, serta adanya protes dari warga. Sosialisasi bukan forum untuk menyampaikan informasi rencana perusahaan, perundingan penggunaan lahan dan meminta persetujuan warga, melainkan forum untuk menjelaskan rencana usaha perkebunan dan pemberian ganti rugi. Masyarakat dipaksa memilih menerima usaha perkebunan dan dengan mekanisme ganti rugi yang sudah ditentukan perusahaan. Hal ini yang terjadi pada tahun 2014 lalu, yang kemudian memenjarakan kepala desa Batu Daya karena menolak cara-cara perusahaan PT. SMP dalam memperlakukan tanah milik warga desa nya.

Perusahaan menggunakan forum pertemuan yang dibentuk masyarakat, seperti Tim Desa, yang terdiri dari aparat pemerintah desa dan tokoh masyarakat untuk menyelesaikan permasalahan pembayaran ganti rugi, pemetaan tanah dan isu-isu, dan sebagainya. Seringkali terjadi perundingan dan pertemuan yang melibatkan perusahaan, warga, Tim Desa, aparat pemerintah kecamatan dan kabupaten, serta LSM, yang disertai dengan Berita Acara kesepakatan kelanjutan pertemuan. Tetapi pertemuanpertemuan yang dilakukan dan isi Berita Acara, tidak pernah secara serius ditindaklanjuti perusahaan, seolah-olah pertemuan dan Berita Acara hanya untuk memenuhi syarat-syarat bahwa perusahaan akomodatif terhadap keluhan dan protes warga, meskipun tidak ada tanda-tanda untuk penyelesaian sengketa, pemberian kompensasi dan ganti rugi yang sesuai, dan tidak adanya upaya untuk mengembalikan tanah kepada pemilik lahan. 
Kemudian, Batas-batas yang sah dari konsesi dan tanah adat tidak jelas dalam peta, atau tidak dikembangkan atau tidak dipetakan bersamasama masyarakat setempat sendiri, atau tidak dijelaskan kepada masyarakat-masyarakat ini, yang menyebabkan kebingungan atas luasan lahan dan tumpang tindih lahan dan hak atas lahan-lahan ini. Hal ini terutama terjadi dimana ada beberapa konsesi di wilayah yang sama, termasuk anak perusahaan dari perusahaan yang berbeda.

Kemudian, juga terus terjadi kurangnya rasa hormat terhadap basis komunal dari hak di kalangan banyak komunitas lokal, dan kecenderungan oleh perusahaan dan pemerintah untuk secara permanen mengindividualisasikan tanah, dengan cara-cara yang bertentangan dengan penguasaan secara adat dan yang menyebabkan ketegangan intra-komunitas.

Pengaturan kompensasi untuk tanah yang hilang karena diberikan kepada perusahaan jarang dirundingkan dengan masyarakat sebelum investasi atau operasi dilaksanakan. Proses pemberian kompensasi untuk tanah yang hilang ini cenderung berlarut-larut dan dilakukan secara individual, bukan berdasarkan FPIC dari masyarakat luas, yang menyebabkan perbedaan pendapat di kalangan masyarakat yang tanahnya dikuasai secara kolektif, sehingga melemahkan sistem tata kelola lahan kolektif.

Agus \& Setyasiswanto (2012) berpendapat bahwa kurangnya identifikasi dini hak guna lahan juga menyebabkan kasus oportunisme dan manipulasi klaim lahan oleh anggota komunitas tertentu atau oleh orang luar, yang menyebabkan kompensasi dibayarkan kepada orang yang salah. Hal ini berdampak tidak hanya pada persinggungan konflik antara perusahaan perkebunan kelapa sawit dengan masyarakat lokal (pemilik lahan/tanah) saja, melainkan juga konflik horizontal antara orang lokal berkonflik dengan orang lokal itu sendiri. Artinya bahwa pihak perusahaan sudah melakukan negosiasi, sosialisasi dan pelibatan orang lokal, baik secara langsung atau tidak langsung melalui perantara, dengan petani perorangan. Hasilnya adalah untuk memecah belah masyarakat, menciptakan persaingan sosial dan politik yang serius.

Pada kasus-kasus perusahaan lain, kompensasi dibayarkan kepada perwakilan desa yang kemudian perwakilan ini tidak mendistribusikannya kepada anggota masyarakat. Dalam hal kompensasi dibayarkan, kompensasi ini cenderung dibayarkan hanya untuk lahan yang hilang tetapi tidak mencakup tanaman dan/atau bangunan yang berada di atas tanah ini, atau untuk manfaat ekonomi yang sebenarnya dapat dihasilkan 
dari tahun ke tahun dari tanaman dan bangunan yang hilang ini. Adanya ketidakadilan ini menjadi pemicu kuat terjadinya konflik pada masyarakat dengan perusahaan.

\section{Kesimpulan}

Sudah bukan merupakan sesuatu yang mengejutkan lagi bahwa ekspansi perkebunan kelapa sawit dalam banyak kasus telah memiskinkan petani setempat dan menyebabkan konflik lahan. Perkebunan kelapa sawit sudah seharusnya menjadi proses pembangunan yang adil melalui reformasi tata kelola, kebijakan dan hukum untuk melindungi hak-hak masyarakat adat dan petani hak atas tanah, mencegah perampasan tanah, memastikan proses negosiasi atas tanah yang adil, membangun kapasitas masyarakat dan menjamin adanya mekanisme untuk penyelesaian (rekonsiliasi) konflik lahan.

Akibat kurangnya penghormatan terhadap hak-hak masyarakat setempat atas tanah adat masyarakat lokal, konflik tanah dengan beragam tingkat keseriusan marak terjadi di sebagian besar perkebunan, mulai dari perselisihan sepele atas tanah, sampai protes seluruh desa, demonstrasi, blokade dan kasus-kasus pengadilan yang berkepanjangan. Sementara perusahaan-perusahaan tertentu telah mengembangkan mekanisme untuk menyelesaikan konflik ini, fokus mereka adalah pada pembentukan proses penyelesaian konflik itu sendiri, bukan pada efisiensi proses ini untuk benarbenar menyelesaikan konflik.

Rekomendasi studi ini yaitu dengan adanya penguatan hak-hak masyarakat melalui pendidikan dan pelatihan tentang prinsip-prinsip hak asasi manusia disertai dengan pendampingan pelaksanaannya dan pengorganisasian masyarakat lokal. Kemudian, harus ada dukungan politik dan hukum dalam penerapan dan pengakuan hak-hak masyarakat atas tanah oleh pemerintah daerah maupun perusahaan. Artinya bahwa paket kebijakan atas keadilan untuk masyarakat adat perlu ada sebagai penguatan posisi tawar masyarakat lokal. 


\section{Referensi}

Agus, A., \& Setyasiswanto, S. 2012. Kesiapan Pemerintah Daerah Melawi, Kalimantan Barat untuk Menyelesaikan Konflik Agraria. Working Paper EPISTEMA. No. $08 / 2012$.

Anonim. 2016. Menimba Fakta 2015, Memicu Spirit 2016. Buletin GAPKI Edisi Januari-Februari. Retrieved from: http://gapki-kalbar.or.id/downloads.php

Badrun, M. 2010. Tonggak Perubahan Melalui PIR Kelapa Sawit Membangun Negeri.

Direktorat Jenderal Perkebunan Kementerian Pertanian Republik Indonesia, Jakarta.

Bahari, S. 2004. Konflik Agraria di Wilayah Perkebunan: Rantai Sejarah yang Tak Berujung. Jurnal Analisis Sosial. Vol. 9(1): 37-45.

Dahrendorf, R. 1959. Class and class conflict in industrial society. Stanford University Press.

Dahrendorf, R. 1990. The modern social conflict: an essay on the politics of liberty. University of California Press.

Nasution, Bismar. 2008. Aspek Hukum Tanggung Jawab Sosial Perusahaan. Makalah disampaikan pada "Semiloka Peran dan Tanggung Jawab Sosial Perusahaan terhadap Masyarakat Lokal Wilayah Operasi Perusahaan Perpspektif Hak Asasi Manusia” diselenggarakan oleh Komisi Hak Azasi Manusia Riau, tahun 2008.

Peraturan Menteri Agraria/BPN No 5 Tahun 1999. Retrieved from: https://www.atrbpn.go.id/Publikasi/Peraturan-Perundangan/Peraturan-MenteriNegara/peraturan-menteri-negara-agraria-nomor-5-tahun-1999-784

Sirait, M. T. 2009. Masyarakat Adat dan Ekspansi Perkebunan Kelapa Sawit di Kalimantan Barat, Indonesia. Fakultas Hukum Universitas Amsterdam dan didanai oleh Cordaid.

Sumardjono, M. S. W. 2010. Harmonisasi Kedudukan Hak Ulayat dalam Peraturan Perundangan Indonesia. Jakarta: Binacipta.

Surambo, A. dkk. 2010. Sistem Perkebunan Kelapa Sawit Memperlemah Posisi Perempuan. Laporan Penelitian Sawit Watch \& Solidaritas Perempuan.

Susan, N. 2010. Pengantar Sosiologi Konflik dan Isu-isu Konflik Kontemporer. Jakarta: Kencana. 
Sutaryono, dkk., 2012. Perjuangan Untuk Menjadi Bagian Dari Proses Perubahan Agraria Yang Menguntungkan (Studi Kasus Perkebunan Sawit di Kabupaten Sarolangun, Jambi), dalam Kebijakan, Konflik, dan Perjuangan Agraria Indonesia Awal Abad 21. Yogyakarta: Pusat Penelitian dan Pengabdian kepada Masyarakat, Sekolah Tinggi Pertanahan Nasional.

Undang-Undang Pokok Agraria No. 5 tahun 1960. Retrieved from: http://kpa.or.id/publikasi/baca/peraturan_kebijakan/12/

Wibowo, A. 2016. Konversi Hutan Menjadi Tanaman Kelapa Sawit Pada Lahan Gambut: Implikasi Perubahan Iklim dan Kebijakan. Jurnal Penelitian Sosial dan Ekonomi Kehutanan. Vol. 7(4):251-260. 